\title{
Analisa Pengaruh Free Cash Flow, Audit Internal, Likuiditas, Leverage Dengan Discreationary Accrual Pada PT. Alsy
}

\author{
Andi Martias \\ Universitas Bina Sarana Informatika \\ Email: andi.aim@bsi.ac.id

\begin{tabular}{ccc}
\hline Diterima & Direvisi & Disetujui \\
21-12-2019 & 23-01-2020 & $05-02-2020$ \\
\hline
\end{tabular}

\begin{abstract}
Abstrak - Discreationary accruals sebagai perwakilan dalam parameter perhitungan manajemen laba. Teori di mana dihitung dengan mengecualikan total akrual dengan non discreationary accrual. Model ini menggunakan Total Accrual (TA) yang diklasifikasik an ke dalam discreationary accrual (DA) dan non discreationary accrual (NDA). Proses penelitian ini bertujuan untuk menentukan proses pengelolaan tanggung jawab manajemen untuk pelaporan keuangan untuk pemegang saham tidak ada informasi yang terlewatkan. Metode manajemen laba adalah bagian dari metode akuntansi yang digunakan dalam pelaporan keuangan untuk investor. Analisis yang digunakan dalam penelitian ini adalah untuk melihat sejauh mana pengaruh arus kas bebas, audit internal, rasio likuiditas, rasio leverage terhadap akrual diskreasiary sebagai perwakilan dari manajemen pendapatan. Pengukuran dengan pendekatan rasio dan hasil dari proses audit internal perusahaan. Sampel perusahaan penelitian jasa di bidang asuransi kerugian yang terdaftar di Bursa Efek Indonesia triwulan 1 hingga triwulan 4 selama periode 2015 - 2018. Data panel regresi digunakan untuk menguji hipotesis. Hasil hipotesis tidak menemukan korelasi yang signifikan antara arus kas bebas, likuiditas dan leverage dengan discreationary accruals. Audit internal dan arus kas bebas mempengaruhi akrual diskresioner dengan tingkat kepercayaan $90 \%$, yang berarti kesalahan standar $10 \%$. Sedangkan leverage dan likuiditas tidak memiliki dampak dengan akrual diskresioner. Ini berarti dengan demikian kinerja keduanya tidak ada korelasi dengan manajemen laba dalam praktik perusahaan yang diteliti.
\end{abstract}

Kata kunci: arus kas bebas, rasio likuiditas, rasio leverage, audit internal, discreationary accrual

\begin{abstract}
Discreationary accruals as a representative in earnings management calculation parameters. The theory in which calculated by excluding total accruals with non-discreationary accruals. This model uses Total Accrual (TA) which is classified into discreationary accrual (DA) and non discreationary accrual (NDA). This research process aims to determine the process of managing management responsibilities for financial reporting for shareholders there is no miss information. The earnings management method is part of the accounting method used in financial reporting for investors.The analysis used in this study is to see the extent of the influence of free cash flow, internal audit, liquidity ratios, leverage ratio to discreationary accrualrs as representatives of earnings management. Measurement with the ratio approach and the results of the company's internal audit process. The research sample service companies in the field of loss insurance which are listed on the Indonesia stock exchange quarter 1 to quarter 4 during the period 2015 - 2018. Regression panel data is used to test hypotheses. Hypothesis results found no significant correlation between free cash flow, liquidity and leverage with discreationary accruals. Internal audit and free cash flow affect discretionary accruals with a confidence level of $90 \%$, meaning a standard error of $10 \%$. Whereas leverage and liquidity do not have impact with discretionary accruals. This means thus the performance of both there is no correlation to earnings management in the practice of the company under study.
\end{abstract}

Keywords: free cash flow, liquidity ratio, leverage ratio, internal audit, discreationary accruals 


\section{PENDAHULUAN}

Informasi yang terdapat di dalam suatu laporan keungan sangatlah berguna seperti informasi keadaan laba perusahaan. Laba dalam laporan keuangan yang telah dibuat oleh manajemen merupakan suatu bagian informasi yang sangat berpengaruh oleh para pemakai informasi laporan keuangan tersebut. Dengan adanya informasi yang akurat maka sangat menentukan bagi para investor dan pengguna laporan keuangan yang lain dalam menganalisa performance dari laporan keuangan tersebut selain manajemen itu sendiri.

Sesuai dengan penelitian yang telah ada dimana menjelaskan bahwa sejauh mana peran laporan keuangan sebagai source information dengan menggunakan pendekatan analisa kinerja sebagai dasar informasi untuk menentukan keputusan sikap terkait investasi terhadap kinerja serta prospek perusahaan tersebut dimasa akan datang (Ghozali, 2011).

Pada penelitian yang berbeda yang dilakukan terkait dengan kinerja keuangan dimana sebagai tolak ukur untuk mengetahui analisa sejauh mana kemampuan perusahaan dalam menjaga stabilitas keuangan perusahaan. Dengan pendekatan Risk Base Capital (RBC) sebagai dasar parameter yang juga menjadi suatu perhatian bagi pemerintah dalam Kep. Men. Keu (KMK) No. 424/KMK/06/2003 merupakan parameter yang bisa menjadi suatu acuan untuk menganalisa kinerja solvabilitas yang menjadi parameter untuk mengetahui sejauh mana perushaan dalam memenuhi pembayaran terhadap hutang-hutang yang ada (Andi Martias, 2017).

Dengan adanya tata kelola perushaan yang baik dan sesuai dengan ketentuan regulator yang ada menggambarkan perusahaan dalam kondisi yang baik. Pada proses pembuatan informasi kinerja keuangan perusahaan pada dasarnya dibuat oleh bagian keuangan karena pada bagianlah yang mengetahui proses dari awal.

Laporan keuangan perusahaan memberikan informasi untuk sumber analisa dasar mengenai performance keuangan kepada pihak-pihak di luar perusahaan. Manajemen perusahaan menyiapkan bagian terpenting dan puncak ketentuan bagi perusahaan sebagai tolak ukur kinerja perusahaan. Disisi lain penanggung jawab di dalam suatu perusahaan, manajemen seharusnya berkewajiban menginformasikan atau tanda-tanda (signaling) mengenai kondisi perusahaan kepada pihak-pihak investor, regulator serta public.

Menurut (Suyono, 2017) manajemen melakukan eksplorasi namun yang tidak sesuai dengan tujuan dan maksud seharusnya. Hal ini terlihat dari adanya pengubahan nilai guna dari proses metode pencatatan yang ada. Earnings management by the company can be efficient (increasing earnings information in communicating private information) and can be subjective (management reports earnings subjectively to maximize personal interests). If earnings management is subjective, the earnings information can lead to wrong investment decisions for investors (Liu \& Yang, 2008). Pada perubahan manajemen yang ada sangat berpengaruh terhadap kinerja kesehatan keuangan perusahaan (Maaloul \& Zéghal, 2015)

Proses yang melakukan action pada pola manajemen laba bisa saja berdampak pada penilaian kredibilitas kinerja laporan keuangan sebagai dasar penentuan investasi, kinerja keuangan terkait laba bisa menggambarkan penilaian laporan keuangan yang merupakan sarana informasi perusahaan dengan public.

Terdapat beberapa hal yang berpengaruh dengan proses manajemen laba diantaranya:

\section{Adverse Selection}

Hal ini terjadi karena beberapa orang seperti manajemen perusahaan dan para pihak dalam (insiders) lainnya lebih mengetahui kondisi perusahaan.

\section{Moral Hazard}

Suatu perbuatan atau tingkah laku yang mencerminkan kondisi tertentu. Hal ini dipakai dalam penentuan parameter kinerja perushaan.

\section{Kinerja Masa Kini}

Kondisi yang menggambarkan ukuran tingkat keberhasilan dalam pencapain suatu goal masa kini yang telah ditentukan dari manajemen.

\section{Kinerja Masa Depan}

Kondisi yang menggambarkan ukuran tingkat keberhasilan dalam pencapaian suatu goal pada masa akan datang yang telah ditentukan oleh manajemen.

\section{Ukuran Perusahaan}

Kapasitas suatu perusahaan berdasarkan volume, skala dan jenis usaha yang dilaksanakan.

6. Penilaian hasil audit

Hasil pemeriksaan audit sebagai dasar parameter pembanding dalam mengukur tingkat manajemen laba.

\section{Komposisi Kepemilikan}

Kondisi menggambarkan besarnya porsi modal yang disetorkan guna melihat sejauh mana dalam keputusan untuk manajemen laba.

\section{Profitabilitas}

Tingkat keuntungan yang diukur berdasarkan tingkat rasio.

\section{Likuiditas}

Tingkat kemamapuan perusahaan dalam melunasi tingkat hutang dengan konsidi uang real yang ada berdasarkan rasio. 


\section{Leverage}

Menunjukan kinerja keuangan pada pengukuran sejauh mana penggunaan sumber-sumber dana yang ada.

Pada proses penelitian yang akan dilaksanakan oleh penulis adalah menganalisa faktor free cash flow, rasio likuiditas, rasio leverage, audit internal berdampak pada discreationary accrual.

Disisi lain kinerja perusahaan signifikan berhubungan dengan nilai tukar dan laba perusahaan yang terkolerasi dengan proses manajemen pada perusahaan (Wiyanti, 2018). Analisa terbatas pada perusahaan-perusahaan perubahan yang telah masuk ke dalam Bursa Efek Indonesia. Menurut (Ali Khan \& Omar, 2013), proses audit dari pihak esksternal bisa digunakan sebagai dasar penilaian dalam menentukan kondisi keuangan perusahaan.

Internal audit sebagai bagian dalam fungsi kontrol perusahaan berperan dalam penilaian untuk perusahaan terkait risiko-risiko yang timbul. (Martias, 2019). Menurut (Diamond, 2013) proses control yang dilakukan oleh internal audit berperan sebagai penyeimbang ketidaksesuaian informasi dalam menginformasikan kinerja keuangan. Proses pengendalian internal yang dilakukan oleh perusahaan dimana tercermin pada proses pemerikasaan berkala baik audit secara operasional maupun audit keuangan dimana hal ini merupakan salah satu cara juga untuk mencegah terjadinya ketidak sesuain proses didalam perusahaan. Laba yang diharapkan juga bisa lebih maksimal tanpa adanya ketidaksesuain pengungkapan (Widyanto, Kwarto, \& Kurniawati, 2018).

Earnings management that occurs in companies audited by auditors including big four KAP is lower than non big four KAP auditors (Bell, Causholli, \& Knechel, 2015). The result is a large auditor size (big audit) is more qualified than a small auditor size (non-big audit). Professional skills of large size auditors have more technical ability to find violations in their client's accounting system compared to small size auditors.

Kepemilikan perusahaan yang semakin besar akan berpengaruh terhadap proses manajemen yang terdapat didalam perusahaan tersebut sehingga sangat sedikit atau tidak mungkin terjadi adanya tindakan manajemen laba yang tidak sesuai. Tindakan earnings management telah memunculkan beberapa kasus skandal pelaporan akuntansi yang secara luas, antara lain pada perusahaan Kimia Farma tahaun 2001 serta Bank Lippo tahun 2002. Pada saat itu perusahaan ini dijatuhkan sanksi dari pihak regulator. Pada penelitian sebelumnya diketahui bahwa analisa terkait free cash flow secara empiris tidak menunjukan dampak yang signifikan didalam proses manajemen laba. Proses ini menggambarkan bahwa free cash flow tidak akan berdampak pada akhirnya kinerja saham yang telah beredar di pasar (Yaari, Nikiforov, Kahya, \&
Shachmurove, 2016). Leverage ratio dalam penelitian lain mengungkapkan bahwa tidak berdampak secara signifikan terhadap manajemen laba. Hal ini menggambarkan tingkat utang terhadap asset tidak memiliki kolerasi terhadap penentuan manajemen laba (Maaloul \& Zéghal, 2015).

Berdasarkan latar belakang di atas maka rumusan masalah dalam penelitian ini adalah: dari pengaruh free cash flow, audit internal, likuiditas, leverage dengan manajemen laba . Tujuan penelitian ini adalah untuk memperoleh bukti empiris pengaruh pengaruh free cash flow, audit internal, likuiditas, leverage dengan manajemen laba.

\section{Manajemen Laba}

Manajemen laba merupakan salah satu faktor yang bisa mengurangi kredibilitas laporan keuangan, serta menambah bias dalam laporan keuangan serta mengganggu pemakai laporan keuangan yang mempercayai angka laba hasil rekayasa tersebut sebagai angka laba tanpa rekayasa.

Manajemen laba bisa dilakukan analisa dengan pendekatan discreationary accrual yang dihitung dengan cara menselisihkan total akrual dengan non discreationary accrual. Model ini menggunakan Total Accrual (TA) yang diklasifikasikan menjadi discreationary accrual (DA) serta non discreationary accrual (NDA). Dalam menghitung discreationary accrual digunakan Modified Jones model dalam penelitian (Suyono, 2017) Model perhitungannya sebagai berikut:

Menghitung nilai total akrual yang bertujuan untuk membisakan parameter untuk menghitung non discretionary accrual (NDA). Total akrual menggunakan persamaan sebagai berikut:

TA $=$ Nit - CFOit

TAit/Ait-1 $=\alpha 1(1 /$ Ait- $)+\beta 1(\Delta$ Recit/Ait- $)+\beta 2$ (PPEit/Ait-1) + Eit

NDAit $=\alpha 1(1 /$ Ait-1) $+\beta 1(\Delta$ Salesit- $\Delta$ Recit $/$ Ait- $)+$ $\beta 2$ (PPEit/Ait-1)

DAit $=$ TAit/Ait-1-NDAit

Keterangan :

TAit : Total akrual perusahaan i pada periode $\mathrm{t}$

DAit : Discretionary accrual perusahaan i pada periode $\mathrm{t}$

NDAit :Nondiscretionary accrual perusahaan i pada periode $\mathrm{t}$

NIit : Net income perusahaan i pada periode $\mathrm{t}$

CFOit :Cash Flow Operating perusahaan i pada periode $\mathrm{t}$

Ait-1 : Total aktiva pada periode t-1 
$\Delta$ Salesit: Selisih sales perusahaan i pada periode $\mathrm{t}$

$\Delta$ Recit : Selisih receivable perusahaan i pada periode $\mathrm{t}$

PPEit : Nilai aktiva tetap perusahaan i pada periode $\mathrm{t}$

Eit : Error

\section{Internal Control}

Dalam pelaksanaan komite audit dibantu oleh internal audit dalam melakukan proses pemeriksaan perusahaan baik secara operasional maupun secara financial. Proses pemeriksaan dilaksanakan secara regular sesuai dengan plan schedule yang sudah ditetapkan. Hal ini memang dituntut independensi dari audit internal dalam melakukan tugasnya.

\section{Leverage Ratio}

Rasio leverage menggambarkan sumber dana operasi yang digunakan oleh perusahaan. Rasio leverage juga menunjukkan risiko yang dihadapi perusahaan. Semakin besar risiko yang dihadapi oleh perusahaan maka ketidakpastian untuk menghasilkan laba di masa depan juga akan makin meningkat. Untuk mengukur leverage ratio dengan persamaan berikut:

Leverage ratio $=\frac{\text { Net Liabilities }}{\text { Total Assets }}$

\section{Free Cash Flow}

Merupakan kas yang dihasilkan oleh perusahaan setelah arus kas keluar untuk mendukung operasi serta mempertahankan aset modal. Tidak seperti pendapatan atau laba bersih, free cash flow merupakan ukuran probabilitas yang mengecualikan pengeluaran non-tunai dari laporan laba rugi, dan termasuk pengeluaran untuk peralatan dan aset serta perubahan modal kerja. Investor pun akan melihat free cash flow ini untuk melihat apakah perusahaan memiliki cukup uang tunai guna mengembalikan modal melalui deviden dan pembelian kembali saham. Perusahaan dengan arus kas bebas (free cash flow) yang tinggi akan memiliki kesempatan yang lebih besar untuk melakukan manajemen laba (Décamps, Mariotti, Rochet, \& Villeneuve, 2011).

\section{Likuiditas Ratio}

Perusahaan dengan likuiditas yang tinggi menunjukkan tingginya kemampuan perusahaan dalam memenuhi utang jangka pendek. Hal ini menunjukkan keuangan perusahaan dalam kondisi yang sehat dan tidak memiliki masalah mengenai arus kas sehingga mampu menanggung biaya-biaya yang muncul. Hal ini sesuai dengan penelitian mengenai likuiditas dimana Rasio Likuiditas menunjukkan kemampuan suatu perusahaan untuk memenuhi kewajiban keuangannya yang harus segera dipenuhi, atau kemampuan perusahaan untuk memenuhi kewajiban keuangan pada saat ditagih (Iqbal \& Ritonga, 2018) Adapun pengukuran rasio likuiditas adalah

Likuiditas ratio $=\frac{\text { Aktiva Lancar }}{\text { Hutang Lancar }} \times 100 \%$
Note:
1. Likuid bila Likuiditas ratio > $100 \%$
2. Illikuid bila Likuiditas ratio < $100 \%$

\section{Audit Result}

Proses audit merupakan suatu proses yang digunakan untuk menggambarkan kualitas suatu perusahaan secara financial dimana hailnya baik berupa penilaian dari performance yang dilakukan terhadap unit yang diperiksa maupun opini yang diberikan oleh hasil dari audit. Keduanya memberikan suatu tolak ukur dalam penentuan keputusan terhadap suatu laporan keuangan yang telah dilakukan proses audit. Definisi penilaian hasil audit yang diidentifikasi oleh Cahan \& Sun, 2015 adalah hasil audit berdasarkan analisa yang dilakukan disimpulkan bahwa probabilitas auditor dalam melaporkan hasil audit dengan opini qualified pada tingkat yang rendah..

\section{Perumusan Hipotesis}

Discretionary Accrual sebagai dari refleksi pengukuran untuk manajemen laba bisa digunakan sebagai acuan dalam penentuan seberapa besar pengakuan yang ada. Free cash flow menggambarkan bagaimana proses arus kas yang dikelola oleh perusahaan. Likuiditas (LKRO) dengan manajemen laba sebagai ukuran untuk menunjukkan bahwa likuiditas tidak berpengaruh signifikan dengan manajemen laba. Leverage (LRO) dengan manajemen laba sebagai dasar ukuran untuk menentukan bukti bahwa leverage berpengaruh signifikan atau tidak dengan manajemen laba.

Hasil dari proses audit internal bisa memberikan pengaruh terhadap tingkat kepercayaan investor. (Andi Martias, 2019) dan (Martias, 2019). Pada penelitian yang lain juga dihasilkan bahwa rating audit yang semakin baik akan berpengaruh postif terhadap discretionary accrual dibandingkan dengan rating yang rendah. Hasil penelitian ini sesuai dengan (Koo, Song, \& Paik, 2015) yang menyatakan bahwa hubungan negatif antara penilaian hasil audit dengan discreationary accrual. Oleh karena itu penilaian hasil audit lebih tinggi bagi auditor size besar dibandingkan auditor size kecil. 
Berdasarkan penjelasan tersebut bisa dirumuskan hipotesis sebagai berikut:

H1: Free Cash Flow berpengaruh signifikan dengan discreationary accrual.

H2: Audit Internal berpengaruh signifikan dengan discreationary accrual.

H3: Likuiditas berpengaruh signifikan dengan discreationary accrual.

H4: Leverage berpengaruh dengan

discreationary accrual.

\section{METODOLOGI PENELITIAN}

1. Data Penelitian

Penelitian pada perusahaan jasa asuransi yang listing di Bursa Efek Indonesia (BEI), dengan penelitian selama 4 tahun pada tahun 2015-2018 dimana sampel dan populasi berdasarkan kuartal 1 sampai dengan kuartal 4 setiap tahunnya. Penentuan data penelitian berdasarkan hasil observasi langsung pada perusahaan bersangkutan dan berdasarkan laporan keuangan yang telah dipublikasi. Pengolahan data dengan menggunakan tool statistic MINITAB program.

\section{Jenis Serta Sumber Data}

Data penelitian kuantitatif sekunder yang diperoleh peneliti secara tidak langsung melalui media internet serta observasi:

1.Data yang berasal dari https://www.idx.co.id/datapasar/laporan-statistik/ringkasan-performaperusahaan-tercatat/, adapun contoh tampilan data pada tabel Financial Data and Ratios sebagai berikut:

Financial Data and Ratios

Public Accountant : Tanudiredja, Wibisana, Rintis, \& Partners

\begin{tabular}{|c|c|c|c|c|c|}
\hline BALANCE SHEET & Dec-14 & Dec-15 & Dec-16 & Dec-17 & Sep-18 \\
\hline \multicolumn{6}{|l|}{ (in Million Rp, except Par Value) } \\
\hline Cash \& Cash Equivalents & 611,181 & 294,441 & 531,583 & 262,292 & 194,577 \\
\hline Receivables & 47,451 & 88,026 & 579,126 & 704,749 & 544,050 \\
\hline Inventories & $1,278,120$ & $1,691,575$ & $2,097,204$ & $2,018,104$ & $2,835,114$ \\
\hline Current Assets & $2,403,615$ & $2,814,123$ & $4,051,544$ & $4,245,730$ & $5,710,846$ \\
\hline Fixed Assets & $8,335,003$ & $9,361,731$ & $10,027,968$ & $10,152,225$ & $10,082,296$ \\
\hline Other Assets & 403,741 & 324,410 & 112,216 & 111,157 & 601,687 \\
\hline Total Assets & $18,558,329$ & $21,512,371$ & $24,226,122$ & $24,935,426$ & $27,318,406$ \\
\hline Growth (\%) & & $15.92 \%$ & $12.61 \%$ & $2.93 \%$ & $9.56 \%$ \\
\hline Current Liabilities & $4,110,955$ & $3,522,133$ & $3,942,967$ & $2,309,417$ & $3,681,899$ \\
\hline Long Term Liabilities & $2,609,888$ & $6,291,451$ & $2,689,673$ & $4,089,571$ & $4,497,548$ \\
\hline Total Liabilities & $6,720,843$ & $9,813,584$ & $6,632,640$ & $6,398,988$ & $8,179,447$ \\
\hline Growth (\%) & & $46.02 \%$ & $-32.41 \%$ & $-3.52 \%$ & $27.82 \%$ \\
\hline Authorized Capital & $2,000,000$ & $2,000,000$ & $2,000,000$ & $2,000,000$ & $2,000,000$ \\
\hline Paid up Capital & 787,373 & 787,373 & 962,344 & 962,344 & 962,344 \\
\hline Paid up Capital (Shares) & 1,575 & 1,575 & 1,925 & 1,925 & 1,925 \\
\hline Par Value & 500 & 500 & 500 & 500 & 500 \\
\hline Retained Earnings & $10,548,430$ & $10,413,840$ & $12,293,945$ & $13,258,048$ & $13,871,057$ \\
\hline Total Equity & $11,837,486$ & $11,698,787$ & $17,593,482$ & $18,536,438$ & $19,138,959$ \\
\hline Growth (\%) & & $-1.17 \%$ & $50.39 \%$ & $5.36 \%$ & $3.25 \%$ \\
\hline INCOME STATEMEN & Dec-14 & Dec-15 & Dec-16 & Dec-17 & Sep-18 \\
\hline Total Revenues & $16,305,831$ & $13,059,216$ & $14,121,374$ & $17,305,688$ & $13,761,630$ \\
\hline Growth (\%) & & $-19.91 \%$ & $8.13 \%$ & $22.55 \%$ & \\
\hline
\end{tabular}

Book End : December
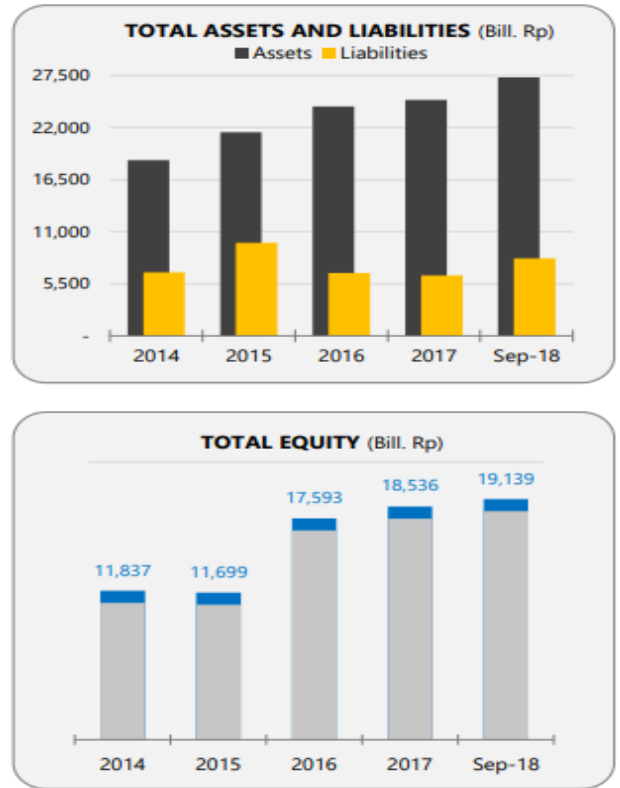

\section{Gambar 1 Financial Data and Ratios}

2.Data yang berasal dari

https://emiten.kontan.co.id/search .

3. Data pengamatam dan observasi penulis.

Data dokumenter dari financial statement yang dipublikasi. Sampel untuk kinerja kuartal 1 sampai dengan kuartal 4 pada tangan 2015 smapai dengan 2018. Pengumpulkan data free cash flow, audit internal, likuiditas dan leverage sesuai dengan discretionary accrual pada periode penelitian.

3.Variabel Penelitian Serta Pengukurannya
A. Variabel Dependen

Model perhitungannya sebagai berikut:

DAit $=($ Tait $/$ Ait-1) - NDAit

Keterangan:

DAit = Discreationary Accruals perusahaan i pada periode $t$

NDAit = Non Discreationary Accruals perusahaan i pada periode $t$ 
B. Variabel independen

\section{Free Cash Flow (FCF)}

Sesuai dengan data yang terdapat pada perhitungan dari laporan keuangan perusahaan terpublikasi.

2. Penilaian hasil audit (KA)

Pengukurun dengan pendekatan 1 untuk perusahaan yang diaudit dan 0 untuk perusahaan yang tidak diaudit sebagai dasar parameter dummy.

\section{Leverage Ratio (LRO)}

Perbandingan antara total kewajiban dengan total aset perusahaan. Rasio ini menunjukkan besarnya besar aset yang dimiliki perusahaan yang dibiayai dengan hutang.

\section{Likuiditas Ratio (LKRO)}

Di ukur berdasarkan kinerja likuiditas yang terdapat pada laporan keuangan perusahaan yang telah di publikasi.

Untuk menguji hipotesis dalam penelitian ini dilakukan dengan menggunakan analisis regresi berganda dengan persamaan regresi bisa dirumuskan sebagai berikut:

$\mathrm{DA}=\mathrm{a}+\mathrm{b} 1 \mathrm{FCF}+\mathrm{b} 2 \mathrm{KA}+\mathrm{b} 3 \mathrm{LRO}+\mathrm{b} 4 \mathrm{LKRO}+\mathrm{e}$
Dimana:

$\mathrm{DA}=$ Manajemen Laba

a $=$ Konstanta

b = Koefisien regresi variabel independen

$\mathrm{FCF}=$ Free Cash Flow

$\mathrm{KA}=$ Penilaian hasil audit

LRO = Leverage Ratio

LKRO = Likuiditas Ratio

e $=$ Error

\section{HASIL DAN PEMBAHASAN}

Data awal yang dilakukan adalah pengumpulan dan pengelompokan data sekunder kuartal 1 hingga kuartal 4 setiap tahun selama periode tahun 2015 sampai dengan tahun 2018 yang diperoleh dari internet selanjutnya dilakukan analisa sesuai dengan ukuran yang telah ditentukan di bab sebelumnya terutama pada pembahasan pada data variable independen. Adapun data yang dimaksud sebagai berikut:

Tabel 1. Pengukuran Data Independen

\begin{tabular}{|c|c|c|c|c|c|c|}
\hline YEAR & PERIODIC & $\begin{array}{l}\text { Discreationary } \\
\text { Acrual (ML) }\end{array}$ & $\begin{array}{c}\text { Free Cash Flow } \\
\text { (FCF) }\end{array}$ & $\begin{array}{l}\text { Audit Internal } \\
\text { Publikasi (KA) }\end{array}$ & $\begin{array}{l}\text { Lukuiditas } \\
\text { (LKRO) }\end{array}$ & $\begin{array}{c}\text { Leverage } \\
\text { (LRO) }\end{array}$ \\
\hline \multirow[t]{4}{*}{2015} & Q1 & 0.0123 & 1.76582 & 0 & 1.2311 & 0.2457 \\
\hline & Q2 & -0.0041 & -0.65421 & 0 & 1.1118 & 2.7632 \\
\hline & Q3 & -0.0142 & 2.9862 & 0 & 0.9789 & 1.8543 \\
\hline & Q4 & 0.0134 & 4.7634 & 1 & 1.4958 & 4.0378 \\
\hline \multirow[t]{4}{*}{2016} & Q1 & 0.0142 & 1.5789 & 0 & 1.1221 & 0.3412 \\
\hline & Q2 & -0.0071 & 1.6893 & 0 & 1.0003 & 1.2333 \\
\hline & Q3 & 0.0272 & 2.1289 & 0 & 1.2133 & 1.7862 \\
\hline & Q4 & 0.0114 & 2.5643 & 1 & 0.9888 & 1.3451 \\
\hline \multirow[t]{4}{*}{2017} & Q1 & 0.0121 & 2.5681 & 0 & 0.9991 & 1.8932 \\
\hline & Q2 & -0.0022 & 2.4371 & 0 & 1.0021 & 0.9871 \\
\hline & Q3 & -0.0133 & 2.8931 & 0 & 1.3321 & 0.2354 \\
\hline & Q4 & -0.0024 & 3.0051 & 1 & 1.5312 & 0.2222 \\
\hline \multirow[t]{4}{*}{2018} & Q1 & 0.0128 & 1.3421 & 0 & 1.4211 & 0.0153 \\
\hline & Q2 & 0.0011 & 3.3423 & 0 & 1.5278 & 0.0231 \\
\hline & Q3 & -0.0233 & 3.4251 & 0 & 2.3101 & 0.0214 \\
\hline & Q4 & 0.0179 & 3.8873 & 1 & 1.6721 & 0.0653 \\
\hline
\end{tabular}

Sumber Pengolahan Data Source Publikasi Financial Statement 2015 - 2016

C. Analisis Data

Statistik deskriptif mengenai discreationary accrual, free cash flow, audit internal, likuiditas, leverage

kuartal 1 samapai dengan kuartal 4 selama periode tahun 2015 sampai tahun 2018. 
Tabel 2. Analisa Deskriptif Variabel Penelitian

\begin{tabular}{|l|c|c|c|c|c|}
\hline & $\mathbf{N}$ & Minimum & Tertinggi & Mean & Std.Deviation \\
\hline DA_(ML) & 16 & -0.0022 & 0.0272 & 0.0035 & 0.0131 \\
\hline CFC** & 16 & -0.6542 & 3.8873 & 2.4827 & 0.0122 \\
\hline KA & 16 & 0.0000 & 1.0000 & 0.2500 & 0.0219 \\
\hline LKRO & 16 & 0.9789 & 2.3101 & 1.3086 & 0.0154 \\
\hline LRO** & 16 & 0.0153 & 4.0378 & 1.0669 & 0.0172 \\
\hline
\end{tabular}

Note: Sumber hasil pengolahan data statistic

Hasilnya discretionary accrual (DA_ML) variabel dependen, dan variabel independen meliputi audit (KA), free cash flow (CFC), likuiditas ratio (LKRO) serta leverage ratio (LEV).

DA_ML memiliki angka terendah -0.0022 dan terteinggi 0.0272 serta rata-rata sebesar 0.0035 . Standar deviasi 0.0131 yang lebih rendah dari nilai rata-rata discretionary accruals menunjukkan rendahnya fluktuasi data variabel DA_ML selama periode pengamatan.

Variabel free cash flow (FCF) memiliki angka terendah -0.6542 dan tertinggi 3.8873, yang berarti bahwa selama tahun 2015-2018 perusahaan menunjukan cash flow dalam kondisi normal karena nilai rata-rata menunjukan 2.4827 dengan standar deviasi 0.0122. Diketahui bahwa data audit memiliki sebaran yang kecil/berada di sekitar nilai rata-rata.

Variabel Audit Internal yang mengukur fungsi audit include eksternal auditor seagai pihak internal untuk laporan keuangan menunjukan nilai rata-rata yang 0.2500 yang artinya fungsi audit sebagai lembaga pengawas independen sudah berjalan dengan baik dan sebaran data juga mendekati nilai rata-rata sebesar 0.0219 tidak terdapat distorsy data yang signifikan. Likuiditas (LIQ) memiliki rata-rata sebesar 1.3086 dengan angka tertinggi 2.3101 dan terendah 0.9789 serta standar deviasi 0.0154 . Hal ini menunjukkan bahwa rata-rata sampel mampu menutup setiap kewajiban lancar perusahaan dengan aset lancar yang dimilikinya. Leverage (LEV) memiliki nilai rata-rata sebesar 1.0669 dengan angka tertinggi 4.0378 dan minimum 0.0153 serta standar deviasi 0.0172. Rasio ini menunjukkan tidak signifikan besarnya aset yang dimiliki perusahaan yang dibiayai dengan hutang yang dimiliki pada periode 2015-2018.

\section{Pembuktian Hipotesis}

Analisis variable yang dilakukan bisa tercermin pada table dibawah ini.

Tabel 3. Analisa Uji Statistik T

\begin{tabular}{|l|c|c|c|c|}
\hline \multicolumn{1}{|c|}{ Model } & Koefi. & T. & Sig. & Null Hypo \\
\hline corresponden** & $\mathbf{3 . 8 1 1}$ & $\mathbf{4 . 0 8 8}$ & $\mathbf{0 . 0 0 1 1}$ & + \\
\hline FCF & -0.315 & -0.913 & 0.07 & - \\
\hline KA & 0.196 & 0.6640 & 0.0940 & - \\
\hline LKRO & 0.211 & 3.835 & 0.121 & - \\
\hline LRO & 0.588 & 3.665 & 0.597 & - \\
\hline
\end{tabular}

Note: Sumber hasil pengolahan data MINITAB

Berdasarkan hasil regresi linear berganda di atas, model persamaan regresi yang dihasilkan adalah: $\mathrm{DA}=3.811+0.315 \mathrm{CFC}+0.196 \mathrm{KA}+0.211 \mathrm{LKRO}$ $+0.588 \mathrm{LRO}+\mathrm{e}$.

Hasil analisis regresi linear berganda dengan uji statistik t tersebut menunjukkan pengaruh dari masing-masing variabel independen dengan variabel dependen. Free cash flow menunjukan nilai t sebesar 0.913 dengan tingkat signifikansi 0.07. Karena signifikansinya lebih besar 0.05 hal ini berarti bahwa variabel free cash flow tidak berpengaruh secara signifikan dengan manajemen laba sehingga $\mathrm{H} 1$ ditolak. Bila ditinjau secara presentase hanya terdapat selisih 0.02 atau $2 \%$, hal ini menunjukan tidak terlalu jauh perbedaan dari ambang batas toleransi 5\%. Apabila dinaikkan tingkat confident level menjadi $90 \%$ artinya standar error $10 \%$ maka $\mathrm{H} 1$ diterima atau terdapat pengaruh free cash flow dengandiscreationary accrual .

Variabel Penilaian hasil audit mempunyai nilai t sebesar 0.6640 dengan tingkat signifikansi 0.09 . Karena signifikansinya lebih besar 0.05 hal ini berarti bahwa variabel penilaian hasil audit tidak berpengaruh secara signifikan dengan manajemen laba sehingga H2 ditolak. Hal ini seperti variabel free cash flow, bila ditinjau secara presentase hanya terdapat selisih 0.02 atau $2 \%$, hal ini menunjukan tidak terlalu jauh perbedaan dari abang batas toleransi 5\%. Apabila dinaikan tingkat confident level menjadi $90 \%$ artinya standar error 10\% maka $\mathrm{H} 2$ diterima atau terdapat pengaruh penilaian hasil audit dengan discreationary accrual.

Variabel leverage mempunyai nilai t sebesar 3.835 dengan tingkat signifikansi 0.121. Karena signifikansinya lebih besar 0.05 hal ini berarti bahwa 
variabel leverage tidak berpengaruh secara signifikan dengan manajemen laba sehingga H3 ditolak.

Variabel likuiditas mempunyai nilai t sebesar 3.665 dengan tingkat signifikansi 0.597. Karena signifikabnsinya lebih besar 0.05 hal ini berarti bahwa variael likuiditas tidak berpengaruh secara signifikan dengan manajemen laba sehingga $\mathrm{H} 4$ ditolak.

Pada koefisien determinasi model regresi diperoleh nilai adjusted $R$ square sebesar 0.56. Hal ini berarti bahwa variabel independen ukuran free cash flow, audit internal, likuiditas ratio dan leverage ratio, serta variabel kontrol ukuran perusahaan mampu menjelaskan perubahan variabel manajemen laba sebesar 56.14\% sedangkan sisanya dipengaruhi oleh faktor lain yang tidak diteliti. Hasil uji statistik F ditunjukkan pada Tabel dibawah ini.

Tabel Analisa Uji ANOVA

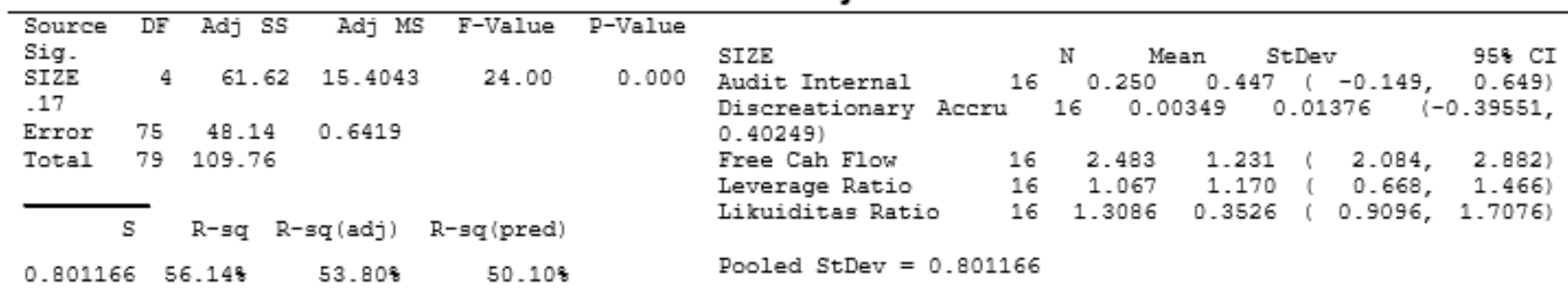

Note: Sumber hasil pengolahan data (uji lampiran)

Hasil uji statistik diketahui nilai $\mathrm{F}$ sebesar 24.00 dengan tingkat signifikansi $0.17(<0.05)$ Hal ini berarti bahwa variabel independen yang terdiri dari ukuran FCF, KA, LRO dan $L K R O$, serta variabel kontrol ukuran perusahaan secara bersama-sama tidak berpengaruh secara signifikan denganvariabel dependen yakni discreationary accrual atau praktik manajemen laba. Hal ini menunjukkan bahwa model regresi dalam penelitian ini benar-benar dapat diterima dan digunakan untuk memprediksi.

\section{KESIMPULAN}

Free cash flow tidak berpengaruh signifikan dengan manajemen laba pada PT ALSY yang terdaftar di Bursa Efek Indonesia (BEI). Namun dinaikkan tingkat confident level menjadi $90 \%$ artinya standar error $10 \%$ maka $\mathrm{H} 1$ diterima atau terdapat pengaruh dengan discreationary accrual. Audit Internal sebagai fungsi kontrol perusahaan tidak berpengaruh signifikan dengan manajemen laba pada PT ALSY yang terdaftar di Bursa Efek Indonesia (BEI). Namun dinaikan tingkat confident level menjadi $90 \%$ artinya standar error $10 \%$ maka $\mathrm{H} 2$ diterima atau terdapat pengaruh dengan discreationary accrual. Leverage tidak berpengaruh signifikan dengan manajemen laba pada PT ALSY yang terdaftar di Bursa Efek Indonesia (BEI) sehingga H3 ditolak. Likuiditas tidak berpengaruh signifikan terhadap manajemen laba pada PT ALSY yang terdaftar di Bursa Efek Indonesia (BEI) sehingga H4 ditolak.

Proses manajemen terkait cash flow diukur dengan menggunakan free cash flow yang tersedia ternyata memberikan pengaruh dengandiscreationary accrual artinya pada manajemen laba.

Peran internal audit sebagai kontrol proses yang ada dalam perusahaan ternyata juga berpengaruh dengan discreationary accrual dengan level tingkat confident level menjadi $90 \%$ artinya standar error $10 \%$ walaupun secara penelitian ini tidak signifikan dikala tingkat confident level menjadi 95\% artinya standar error 5\%. Hasil ini juga terdapat faktor dari eksternal audit sebagai pihak eksternal independen yang melakukan proses audit dengan financial statement yang kemudian dipublikasikan. Hasil ini menunjukkan bahwa audit result memberikan pengaruh dengan proses akuntansi dalam perusahaan terutama pada penetuan proses manajemen laba.

\section{REFERENSI}

Ali Khan, M. N. A. bin, \& Omar, N. A. B. (2013). A study of importance items of internet financial reporting: A case of malaysian auditors. Middle East Journal of Scientific

Research. https://doi.org/10.5829/idosi.mejsr.2013.18. 3.11902

Andi Martias. (2017). Interaksi pengalaman, indenpendensi, kompetensi, etika auditor dan insentif moneter terhadap hasil pemeriksaan. Konfrensi Nasional Ilmu Sosial Dan Teknologi.

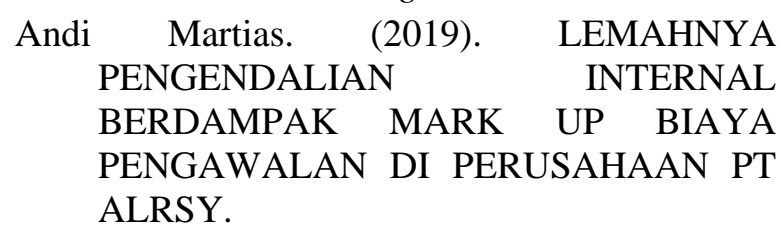

Cahan, S. F., \& Sun, J. (2015). The Effect of Audit Experience on Audit Fees and Audit Quality. Journal of Accounting, Auditing and

Finance. https://doi.org/10.1177/0148558X14544503

Décamps, J. P., Mariotti, T., Rochet, J. C., \& Villeneuve, S. (2011). Free Cash Flow, Issuance Costs, and Stock Prices. Journal of Finance. https://doi.org/10.1111/j.15406261.2011.01680.x

Diamond, J. (2013). Internal control and internal audit. In The International Handbook of Public Financial Management (pp. 374- 
395).

https://doi.org/10.1057/9781137315304

Ghozali, I. (2011). Aplikasi Analisis Multivariate Dengan Program IBM SPSS 19 (edisi kelima). Aplikasi Analisis Multivariate dengan program SPSS. https://doi.org/10.9744/jmk.10.2.pp. 124135

Iqbal, M. ., \& Ritonga, A. . (2018). OPTIMALISASI PORTOFOLIO SAHAMSAHAM LQ-45 DENGAN MENGGUNAKAN CAPITAL ASSET PRICING MODEL. KARISMATIKA: Kumpulan Artikel Ilmiah, Informatika, Statistik, Matematika Dan Aplikasi. https://doi.org/10.24114/jmk.v4i1.11859

Koo, J.-H., Song, S., \& Paik, T.-Y. (2015). Earning Management and Cost stickiness. https://doi.org/10.14257/astl.2015.84.09

Liu, C., \& Yang, D. (2008). The Effect of the $\mathrm{CEO} / \mathrm{CFO}$ Certifications on Earnings Management. Journal of Theoretical Accounting Research.

Maaloul, A., \& Zéghal, D. (2015). Financial statement informativeness and intellectual capital disclosure. Journal of Financial Reporting and Accounting. https://doi.org/10.1108/jfra-04-2014-0023

Martias, A. (2019a). Analisa Peran Komunikasi dan Psikologi Audit Dalam Proses Audit di PT.Alarsy. Persepektif.

Martias, A. (2019b). ANALISA PERANAN KOMUNIKASI DAN PSIKOLOGI AUDIT DALAM PELAKSANAAN TUGAS DI PT ALARSY. Jurnal Perspektif. https://doi.org/10.31294/jp.v17i1.4791

Suyono, E. (2017). Bebagai Model Pengukuran Earnings Management: Mana Yang Paling Akurat. Sustainable Competitive Advantage-7 (Sca-7) F.

Widyanto, M. L., Kwarto, F., \& Kurniawati, S. (2018). PENGARUH KOMPETENSI, ETIKA, DAN PENGALAMAN KERJA TERHADAP KUALITAS AUDITOR INTERNAL. Jurnal Profita, 11(2), 165. https://doi.org/10.22441/profita.2018.v11.0 2.002

Wiyanti, R. (2018). ANALISIS PENGARUH 7 DAY RATE REPO, INFLASI, NILAI TUKAR, DAN PDB TERHADAP INDEKS HARGA SAHAM SEKTOR PROPERTI (STUDI EMPIRIS DI BURSA EFEK INDONESIA). Jurnal Akuntansi : Kajian Ilmiah Akuntansi (JAK). https://doi.org/10.30656/jak.v5i2.666

Yaari, U., Nikiforov, A., Kahya, E., \&
Shachmurove, Y. (2016). Finance methodology of Free Cash Flow. Global Finance Journal. https://doi.org/10.1016/j.gfj.2015.05.003

\section{PROFIL PENULIS}

Andi Martias SE, M.Si, Ak, QIA lahir Palembang, Sumatera Selatan, menyelesaikan SI di Universitas Islam Indonesia di Fakultas Ekonomi, Jurusan Akuntansi, S2 di Megister Sience Universitas Gadjah Mada Yogyakarta (UGM), Pendidikan Profesi Akuntansi di Universitas Sriwijaya Palembang (UNSRI) dan Qualified Internal Audit (QIA) di Yayasan Pendidikan Internal Audit Jakarta (YPIA). Aktif sebagai dosen di Universitas Bina Sarana Informatika, praktisi di perusahaan dan aktif sebagai anggota Ikatan Internal Audit (IIA). 